\title{
Gerschenkron Revisited: The New Corporate Russia
}

\begin{abstract}
Based on firm-specific data compiled from the Russian Trading System stock exchange and SKRIN database, this paper seeks to identify the factors behind Russia's dramatically improved corporate sector performance approximately from the beginning of the new millennium through December 2007. We argue that improved corporate long-term performance was a consequence of several policy initiatives associated with the state-dominated banking sector that enabled statesubsidized investment funds to be channelled from a structurally re-engineered energy sector to targeted investment projects located in other industries. We argue that Russia's industrial strategy closely conforms to Gerschenkron's catch-up theory.
\end{abstract}

Key Words: Gerschenkron, Russian banks, state-directed subsidy

JEL Codes: P26, O38, O43 


\section{Introduction}

In this paper we test the effect of reforms, which were introduced in Russia at the beginning of the millennium in the banking industry. Such reforms were designed to improve the efficiency of both the allocation and utilization of state-subsidized investment funds to targeted corporations located in favored economic sectors. The banking reforms were an integral part of an overall strategy by the early first Putin regime designed to promote long-term corporate performance, an important aspect of which was to more closely involve the central state in firm-level investment decision making.

Following Gerschenkron (1962), and later Doh et al. (2004) and Vaaler and Schrage (2009), in this paper we concentrate on the potential role of the state in improving corporate performance. Vanteeva and Hickson (2012) argue that corporate reforms introduced by the state worked specifically to better assure both the state and other outside investors against the propensity of inside investor-managers (oligarchs) to asset-strip firm assets, behavior which infamously rose to epidemic proportions during the Yeltsin regime's privatization of industry initiative (Hoffman, 2002; Hoff and Stiglitz, 2004).

Specifically, our focus is on measuring the effect of investment funds on firm-level long-term performance. However, we also measure the effect of the series of state reforms of the energy sector during the period, which enhanced energy-sector earnings to the government. We also test the effectiveness of the banking system reorganization during the period, which was brought under state control (Vernikov, 2007; Kalyuzhnova and Nygaard, 2009). While under the previous Yeltsin regime's privatization scheme, state funds were also channelled through banks, the banks operated without effective monitoring. This led to a rapid growth of under-funded 
banks with maleficent business practices, and through such banks the quasi-owner managers in charge of former state enterprises were able to transfer misappropriated funds abroad. As is widely known, in situ managers widely asset-stripped their former state enterprises (for e.g. Black et al., 2000; Sonin, 2000). Thus under the former Yeltsin regime such funds simply evaporated through the banking system.

After bank restructuring, as we explain below, the flow of loanable funds channelled through the state-controlled banking system had a significant effect on firm long-term performance. We argue that such evidence of improved long-term corporate performance is de facto evidence of a reduction in hold-up behavior on the part of owner-managers of firms and lower-level bureaucrats, both of whom are widely believed to be the most likely culprits of firm assetstripping during the worst years of the Yeltsin regime.

Our study presents an opportunity to revisit Gerschenkron's 'catch-up theory', particularly as he applied it to Tsarist Russia. Gerschenkron, in general, based his theory on his observations on the pattern of industrialization of European countries during the latter half of the nineteenth and the first decades of the twentieth centuries. He postulated that the more backward the economy, the greater was its potential for rapid industrial growth achievable through borrowing the advanced technology of its more developed neighbors (Gerschenkron, 1962: 8-9). He added that rapid industrialization could be achieved even if the adopting economy lacked its own sufficient pools of skilled labor or a sufficient supply of free unskilled labor as the former could be imported, while labor saving technologies could be substituted for the latter. For this reason, during this period, he believed that relatively backward economies tended to industrialize using highly capital-intensive basic industries with large-scale plant production. 
The technology characteristics mentioned above, combined with the push to simultaneously generate growth in several complementary industrial sectors, created a demand for large flows of investment funds. Gerschenkron observed that in countries such as France, Germany and Austria, this demand was met by the evolution of new form of investment banking, called unified banks. Unified banks, like the older English deposit banks, collected savings from a wide net of depositors, but differed from them in that they were designed to make large and long-term investments in specific large-scale industrial firms. This strategy also required that they also actively monitor their firm-specific investments by playing an active role in corporate governance (Gerschenkron, 1962: 11-16).

Gerschenkron argued that Russia's delayed industrialization was due to the truculence and moral turpitude of its conservative ruling classes. In particular, the failure of the country to develop necessary prerequisite institutions, such as a property-protecting legal system, a business-friendly state bureaucracy or a capable banking and financial system. His assessment of the existing ruling class was, in large part, based on the failure of the earlier reforms under Nicholas II. For example, the spread of Western-inspired intellectual ideas among younger urban elites during the mid-nineteenth century had, inter alia, promised the prospect of the adoption of a Western-style commercial judicial system to replace the existing inquisitorial system. The latter was prone to capricious political and bureaucratic interference and Gerschenkron and others blamed it for fostering a climate of dishonesty prevailing at the time in Russian commercial relationships. Widespread dissatisfaction with the inquisitorial system fuelled a dramatic increase in students studying Western law. Some accounts estimate that over fifty percent of Russian university students by the end of the 1860s were studying Roman law (Smith, 1996). 
The wave among a new elite calling for judicial reform succeeded in a having a new legal code adopted, which, inter alia, adopted civil statutes based on those of Hanover. In addition, reforms in jurisprudence led to, at least on paper, a system of independent courts with jury trials and the creation of a professional bar association. However, from the outset, the legal reforms were strongly opposed by powerful elements within the traditional ministries, and the old inquisitorial system continued to prevail in the provinces. An independent judiciary would always prove to be difficult to sustain under an autocracy, and during the conservative reaction that followed the assassination of the reforming Tsar in 1881, the new legal reforms simply failed to take root (Smith, 1996).

Regarding nineteenth-century Russian banking, though there may have been numerous owners with substantial liquid savings (e.g. Falkus, 2008), the country's banks lacked the ability to expand their deposits. The also lacked the ability to channel such deposits to meet the demands for large-scale industrial investment. For example, there existed only a few small deposit banks. Furthermore, these banks were guilty of widespread maleficence. Consequently they were widely distrusted (e.g. Chandrasekhar, 2005). In Gerschenkron's own words, Russian banking during this period had 'elevated fraud to the level of general business practice' (Gerschenkron, 1962: 20).

Finally, the perverse manner in which the serfs were emancipated in the 1860 s impeded the free movement of rural labour into industry. Though the former serfs received allocations of land from the rural aristocracy, the transfer prices set by the government were greatly above market prices. The former serfs were therefore saddled with large debt levels, which led to unavoidable high redemption levies. Newly established village communes, or obshchina, were held collectively responsible for all the debts and taxes of its villagers. Thus they were empowered to 
collect the debts and taxes from its constituent peasant families. The communes even had the power to demand such payments from former villagers working in cities, and to demand the return of villagers who were working in industry. Such barriers to labour mobility remained until eliminated under the Stolypin reforms of 1906 and 1910.

\section{Russia's industrialization under Vyshnegradsky and Witte}

Beginning under Ivan Vyshnegradsky in the 1880s, and in later decades under Sergei Witte, a state-owned railway network was built, eventually spanning the entire country. In the 1890s, the pace of industrialization accelerated with new enterprises launched in the iron, coal and machine tools industries, all of which were partially or entirely state-funded with money raised through both indirect and direct taxes (Gerschenknron, 1962:17). For example, the iron, coal and railway sectors were particularly subsidized (Willis, 1897; Tompkins, 1933; Drummond, 1976; Gatrell, 1994). Other policy reforms extended protection from competition to the new industries. New high import tariffs were erected and the government encouraged cartelization of firms. This allowed industrial firms to set high domestic prices. The state also extended them high profit guarantees.

During the same period, the country adopted the gold standard. It did so in order to attract large amounts of foreign loans. Foreign capital was also encouraged to invest heavily in the new industries through subsidiaries operating under state license (Hogan, 1993). Gerschenkron postulated that the monetary reforms attracted substantial levels of foreign capital, which ended up funding a significant portion of the country's industries. Many scholars confirmed this to be the case (for instance, Crisp, 1953; Miller, 1967; Gregory, 1991). 
Gerschenkron argued that the path of Russian economic transformation was sui generis in that it was through the agency of the state. There is some evidence that a few industrial firms may have been established independently through private capital (Crisp, 1973: 590). However, the scale of the Russian industrialization plans required the marshalling of large resources under a statemandated plan. The Russian experience most likely encouraged Gerschenkron to believe that a country could always find an alternative path to industrialization. However, he also postulated that the Russian state's motivation was to modernize its military capability (Gerschenkron 1962: 17).

The Russian industrialization drive achieved dramatic results (Gerschenkron, 1962; Gregory, 1991). For example, Russian railways between 1880 and 1900 experienced higher growth than even the US. ${ }^{1}$ Iron and coal output increased by about four times during the 1887-1899 period and an industrial boom spurred a surge in construction (Geyer, 1987). Nevertheless, there were negative aspects to Russia's rapid industrial transformation, having to do with an inefficient mix of output. The most important aspect of this was fall in agricultural output due to the heavy taxes imposed on it. The policies also suppressed consumer goods production in favor of capital goods production. In addition, high import tariffs, high tax rates, and cartel-pricing for industrial products, all combined to produce a de facto policy of forced savings on the unlucky generation of Russians that happened to shoulder them at the time. Gerschenkron argues that the severity of the forced-savings policy varied according to the exigencies of military needs. This, he argued, led to a pattern of industrialization by fits and starts, characterized by periods of accelerated

\footnotetext{
${ }^{1}$ Between 1880 and 1900, Russian railways registered a growth rate of approximately 133 percent, while US railway attained a growth rate of approximately 113 percent. However, in real terms, the US had 193 thousand miles of track, compared with only 35 thousand miles in Russia (see Fordham University Modern History Sourcebook: Tables Illustrating the Spread of Industrialization, Historical Statistics of the United States: Colonial Times to 1970, and Encyclopaedia of World History: Age of Revolution and Empire, 1750 to 1900).
} 
production levels followed by periods of sectorial recessions, such as the recession in the early 8090 s, the worst aspect of which was a dire agricultural depression.

In summary, Gerschenkron offers an intuitive insight for jump-starting industrialization in backward economies through borrowing technology from more developed economies. We add that the Vyshnegradsky-Witte strategy was also an effective second-best strategy for jumpstarting the Russian economy beginning in the late nineteenth century. Large-scale industrialization spurred by the government may have been impossible otherwise due to latent predatory behaviour of local bureaucrats and firm owner-managers. Gerschenkron's model, despite much criticism, remains a viable alternative for current backward economies facing similar problems (Crisp, 1991; McCloskey, 1991). In this paper, we argue that the present Russian government strategy can be described as Gerschenkron-esque, in that the state is once again involved in allocating subsidized investment funds to targeted commercial sectors.

Lastly, while our emphasis in this paper addresses only the narrow issue as to the efficiency of the efficacy of the Putin regime's reforms during our sample period, perhaps in sympathy to Oliver Williamson's view that it is efficiency and not exercise of power that explains economic organization (Dugger, 1990). Nevertheless, the ability of state power in Russia to distribute resources in favor of particular groups is obvious. For example, as we noted above, the Yeltsin regime worked to favor existing managers of former state enterprises and local bureaucrats, while the Putin regime is found to favor long-term St. Petersburg associates (Nilsen, 2006). This aspect of Russian corporate history may conform to the perspective of the old institutional economics that state power is necessary in order to distribute resources (Kanel, 1974; Macneil, 1980; Palermo, 2000). The history may even conform to the hypothesis that the state defines the 
boundaries of economic activity by supporting certain power relationships (Parto, 2005). However, we leave these aspects of Russian corporate history to future study.

\section{Changes in state policy underpinning Russian corporate revival}

\subsection{Significant changes in state energy policy}

Dramatic improvement in the performance of the Russian corporate sector began at the turn of the new millennium. Indubitably a fortuitous sharp rise in export revenue attributable to a substantial increase in world energy prices was a major factor (Tabata, 2002). For example, from the early to mid-2000s, the value of oil and gas exports increased to approximately 60 percent of total export earnings. The energy sector accounted for about 30 percent of all foreign direct investment, and together oil and gas industry earnings accounted for 30-40 percent of government's total revenues (Rautava, 2004). ${ }^{2}$

Gaddy and Ickes (2005) split natural resource rents into five different components, such as formal taxes, profits, price subsidies, informal taxes and excess costs of production. In this paper, we simply treat rents as revenue obtained from the sale of resources less the cost of production (Gaddy and Ickes, 2005). Vdovichenko and Voronina (2006) and Hanson (2007) find that such rents funded investments in other industries deemed nationally important (Peshkova, 2008). Their findings are consistent with the stated directive that specified a redistribution of energysector rents to other favored industrial sectors (Butt et al., 2008). For this purpose, a Stabilization Fund was established, which was divided into a Reserve Fund and National Welfare

\footnotetext{
${ }^{2}$ Energy Information Administration (Official Energy Statistics from the US Government).
} 
Fund. By 2007, this fund had an estimated value of 158 billion dollars, constituting approximately 12 per cent of country’s GDP (Ericson, 2009). ${ }^{3}$

The amount of available funds for redistribution from the energy sector crucially depended on the bargaining power of the state vis-à-vis foreign and domestic energy companies (Osipov, 2006). One would expect the central state to win the lion's share of rents over many competing firms, as it enjoys a monopoly of issuing licences for exploration and extraction contracts. ${ }^{4}$ Yet on reflection, we should expect that the state's negotiating power depends on its ability in preventing energy companies, through side payments, from exploiting latent rivalry amongst its local government officials. This problem would be more severe in the case of multinational conglomerates.

There is a long history of predatory behaviour by regional state officials in Russia, perhaps in part because they view it as a traditional right. For example, in the $14^{\text {th }}$ century, under the sistema kormleniya, regional bureaucrats were allowed by the Tsar to 'exploit their constituencies for private gain' (Ledeneva and Shekshnia, 2011:7). Peter the Great made such extortionary behavior illegal, and despite numerous later legal reforms it persists. For instance, a common practice is to disrupt tendering processes through informal networks in order to extort bribes. In particular, local bureaucrats commonly block approvals for oil exploration and extraction licences (Adachi, 2009). ${ }^{5}$

\footnotetext{
${ }^{3}$ National Welfare Fund is also used to support social welfare.

${ }^{4}$ Under contractual agreement, the central state offers an investor an exclusive right to explore and extract resources from a specific geographical location for a certain period of time (Heinrich et al., 2002).

${ }^{5}$ Dmitriev (2004) draws attention to Vladimir Butov, a regional official who was accused of withholding a licence approval for a major oil-field development in Northern Russia. There were also criminal proceedings issued against Butov for his efforts to get a licence for Lukoil in 2001 (Akhtyrov, 2003).
} 
During the 1990s, oligarchs dominated major energy firms to the point that they controlled most of the oil sector (Wolosky, 2000; Hill and Fee, 2002; Hoffman, 2002; Guriev and Rachinsky, 2005). Significantly, the energy-sector oligarchs, often in collusion with local government officials, rushed to form lucrative partnerships with foreign oil firms (Hill and Fee, 2002). They also freely misappropriated assets of their enterprises (Barnes, 2007). Such practices, in conjunction with falling oil prices, caused a decrease in the value of oil production by approximately 50 percent between 1988 and 1998. As energy-sector rents declined to minimal levels, investor-managers amassed high personal fortunes.

Under the Putin regime asset-stripping declined substantially, however, as Gaddy and Ickes $(2005,2009)$ point out, persisting weak property rights still encouraged firm owners to overly discount their firm's capital. The authors also argue that the state often informally shares energysector rents with private firms in compensation for insecure property rights. However, our focus is particularly on performance of long-term projects, requiring longer-term investment horizons.

Beginning early in the Putin regime tenure, the central state's exerted greater control over the oil industry through a series of regulatory changes, and through a partial re-acquisition of energy sector firms (Sagers, 2006). Hanson (2009) finds that between 2003 and 2007 the percentage of companies controlled by the state increased from 24 percent to just below 40 percent. Also, the change in the Subsoil Law of 2002 granted the federal government exclusive ownership over resources, with exploration and production rights then leased to private agents. Over this period, there was an increase in Production Sharing Agreements, and foreign investors were attracted, though with limited extraction privileges, to particular natural resource deposits. 
International companies were encouraged to enter joint ventures in the Russian hydrocarbon industry, but only by forming partnerships with native Russians who held majority stakes (Erochkine and Erochkine, 2006; Locatelli, 2006; Hanson, 2009). Gaddy (2004) suggests that foreign firms were encouraged to invest in order to undermine dishonest oligarchs (Gaddy, 2004:350). But the government also encouraged joint ventures with state-owned companies, as in the case of Rosneft and Exxon Mobil for the purpose of exploiting Artic-shelf resources. However, one can also rationalize such partnership requirements as designed to diffuse industry technology. There is also the rationalization that the government hoped to increase the future pool of bidders for new extraction licenses. Consequently, future bargaining power of the state would be increased vis-à-vis international conglomerates. This would have also enhanced the state's present bargaining power as the industry was growing at the time.

Despite the restrictions listed above, foreign investors received substantial earnings during this period and thus were keen to partner in developing Russia's natural resource base (Hare et al., 2004; Ehrstedt and Vahtra, 2008). ${ }^{6}$ For instance, energy firms from France, Norway, Germany, Italy, Netherlands, the US and Japan all invested in the sector. Between 2000 and 2006 the Russian stock market rose by approximately 500 points. Furthermore, over 40 percent of this growth was attributable to two major oil companies, Gazprom and Rosneft, both of which operated as partnerships between the state and foreign investors (Harris, 2009). In particular, the UK during this period was the largest source of foreign investment in the energy sector, with British Petroleum enjoying profits amounting to over four times its initial investment. ${ }^{7}$

\footnotetext{
${ }^{6}$ In 2003, the Yukos case attracted a lot of negative media attention, when the former head of the company, Mikhail Khodorkovsky, was placed under arrest for tax evasion and Yukos assets were subsequently sold to state-owned company Rosneft. While this case had an adverse effect on Russia's investment climate, this impact was short-lived.

${ }^{7}$ Twilight for BP in Russia, The Economist, 9 June 2012.
} 
However, high earnings enjoyed by foreign oil companies may simply reflect the level of risk associated with long-term, large, lumpy and asset-specific investments in an uncertain political and legal environment (Reynolds and Kolodziej, 2007). But, correspondingly, the reforms outlined above, also worked to increase state coffers through enhanced revenue.

\subsection{A re-vitalisation of the banking sector}

It is often asserted that increased funds from enhanced natural-resource earnings are sufficient to explain Russian corporate revival during this period. However, such a view fails to grasp the magnitude of the pre-existing moral hazard problems that had led to actual divestment in many enterprises during the previous Yeltsin regime. Consequently, it is of particular interest to assess the effectiveness of the new regime's reforms of the banking system.

Under the Yeltsin privatization scheme, banks operated without effective constraints leading to an explosion of under-funded banks, for which reason were termed 'mushroom' banks (Gidadhubli and Kumar, 1999). Understandably, such banks were fraught with moral hazard problems and consequently were infamous for issuing large quantities of poorly-defined financial instruments, typically far in excess of bank assets. In addition, the new breed of bankers generally had little to no previous bank management track record of experience. ${ }^{8}$ Thus, the new banks engaged in highly risky investments, which fuelled speculative bubbles. The schemes were to such a degree that their investment portfolios amounted to little more than a series of Ponzi schemes accompanied by implausible promises of high returns designed to lure individuals with small savings. The end came when the system of 'mushroom' banks collapsed in spectacular

\footnotetext{
${ }^{8}$ Due to incompetent decision-making and concentrated lending to favoured firms and individuals, defaulted loans represented 10 percent of country's GDP by 1997 (Meyendorff and Snyder, 1997).
} 
fashion overnight into insolvency (Pistor and Spicer, 1997; Rock and Solodkov, 2001; Bhattacharya, 2003).

Nonetheless, the manager-owners of new financial intermediaries had strong political ties to the Yeltsin regime. Thus, unsurprisingly, the management of such banks, during this period, facilitated the transfer of misappropriated company funds abroad at the behest and in the favor of the new quasi-owner managerial elite (Gidadhubli and Kumar, 1999; Berglof and Bolton, 2002; Laeven, 2001; Thomson, 2002; Spicer and Pyle, 2003; Buyske, 2007). Moreover, even central bank funds that were initially targeted for various investment projects were reportedly also misappropriated by government officials and other insiders. Large amounts of central banks funds were routinely converted into US dollars through the newly constituted Russian foreign exchange market, and they too ultimately found their way into the personal overseas accounts of these officials (Rock and Solodkov, 2001).

The above developments came to a head during the financial crisis of August of 1998, which culminated in the collapse of the currency and the suspension of its payment system. For example, the state postponed payments on foreign debt and defaulted on its rouble-denominated public debt (Sutela, 2000), inevitably forcing the Russian government to borrow substantially from several world organizations, such as the World Bank and the IMF (\$6.3 billion and \$19.3 billion, respectively by the end of 1998). ${ }^{9}$ Part of the package was a demand by the country's foreign creditors and the IMF to require restructuring of the Russian state's payment system in order to meet the nation's debt obligation (Scharf, 2006).

\footnotetext{
${ }^{9}$ See http://www.law.harvard.edu/programs/about/pifs/llm/sp26.pdf.
} 
Sequential to the IMF mandated restructuring of the Russian foreign credit system, at the turn of the millennium, was a reform of the banking system to prevent a recurrence of casino style banking. Other banking reforms aimed to prevent the use of banks from surreptitiously misappropriating the funds of large industrial enterprises. For example, the government established the Agency for Restructuring Credit Organizations, which was responsible for making sure that 'bad' banks were closed, while also re-capitalizing potentially profitable banks and creating a deposit insurance scheme, which was back-stopped by the state. ${ }^{10}$ One crucial outcome was the revitalization of the role of the Savings Bank of Russia's Federation (Sberbank), which had been allowed to languish under the Yeltsin regime. Sberbank emerged after the financial crisis of 1998 as the only bank trusted by savers and investors (Shakina, 2001; Buyske, 2007; Peresetsky et al., 2007). Part of the banking restructuring of Sberbank included its acquisition of the assets of eight of Russia's largest banks during the period. Consequently, by 2005, Sberbank was so dominant that it was reported to hold over 80 percent of consumer deposits. One can estimate that through Sberbank and the other large state-owned bank called Vneshtorgbank, the state-owned banks directly controlled 41 percent of banking sector loans. But this estimate is much too low, because the state also acquired a substantial stake and exercised a considerable influence on the management of several other large and medium banks.

Johnson (2004) points out that in 2002 the regime introduced amendments to the Law on the Central Bank that set up the National Banking Council. This Council was predominately made up of government official and began to increase control over the Central Bank's activities. Inevitably, these initiatives led to increased direct and/or indirect state ownership of banks. For instance, Vernikov (2010) finds that state-owned banks had combined assets of 15.8 trillion

\footnotetext{
${ }^{10}$ See Russia's Uncertain Economic Future, Compendium of Papers submitted to the Joint Economic Committee Congress of the United States, 2001 and Chernykh and Cole (2010).
} 
roubles by 2010 , in contrast with approximately 1 trillion roubles in assets in 2001. In addition, the market share of state-controlled banks reached almost 54 percent in 2010, compared to 36 percent in 2001, where indirectly state-owned banks tended to grow faster than all other types of banks. This estimate is consistent with Fungacova and Solanko (2009), who find that the state's ownership share in the banking industry accounts for approximately 50 percent of banking sector's assets, and the five state-controlled banks account for 37 percent of those assets (Anzoategui et al., 2012).

Nevertheless, after the above banking reforms, there remained several private pocket or oligarchic banks, which tend to be owned by enterprises located in the extracting and metallurgical industries. Such banks primarily offer financial services, such as overseeing these companies' accounts, as opposed to acting as financial intermediaries (Gnezditskaia, 2003; Styrin, 2005). However, the number of such banks remains relatively small and public banks overtook both private domestic and foreign banks (Vernikov, 2009).

Despite the above reforms, Alphonse et al. (2006) argue that Russia's banking sector is still fraught with moral hazard problems and is still incapable of satisfying the borrowing requirements of industry. ${ }^{11}$ Kirdina and Vernikov (2013) do a further analysis of the Russian banking sector and find that private banks were always incapable of supporting country's growth, while state banks have a significant impact on liquidity, and more importantly, are traditionally employed as vehicles for lending on the behalf of the state. It is perhaps in response to such concerns, a new a New Investment Fund in 2000 was founded. The Fund was set-up for the purpose of 'assisting in the development of basic strategic industries, first and foremost, of

\footnotetext{
${ }^{11}$ Also, the vice-president of Rosbank, one of the major Russian banks, has recently stated that although private investors are aware of potential attractiveness of the Russian banking sector, its present form is shaped by many risks (Organizaciya prodazh bankovskih produktov, 2007).
} 
transport, communications and utility infrastructure, as well as technology and innovation' (Budget Reform in Action, 2006-2008, pg. 4). Yakovlev and Zhuravskaya (2006) find that state subsidies and state-subsidized loans almost doubled between 2000 and 2003 over the 1996-1999 period. Similarly, Vedev (2008) finds that state subsidies were in the form of direct funds as well as subsidized credit interest rates or credit guarantees. ${ }^{12}$

Although many (for e.g. Fungacova and Solanko, 2009) find that that banks' credit to firms increased dramatically over the period, financial intermediaries accounted for a small amount of company financing, with firms tending to more rely on retained earnings and syndicate loans. However, we argue that the role of banks may be under-represented as a large proportion of the flow of targeted investment funds may be shepherded through the state-banking sector. In addition, the banks are also more closely monitored by the Central Bank of Russia, which requires all commercial banks to license investment funds offered to every credit institution. With enhanced state monitoring and rationing of investment funds, many private and most of semi-private (especially large) firms may be financed through government-influenced loans. For example, Gnezditskaia (2003) notes that blue-chip and natural resource companies are the main borrowers of Sberbank.

More generally, it is reported report that the expansion of state banks after the August 1998 crisis in Russia was accompanied by significantly increased lending (government banks' loans grew by approximately 80 percent, Havrylchyk, 2004), as well as major expansion in long-term credit instruments (Sutela, 2005). Fungacova and Weill (2009) find that banking credit amounted to 40 percent of GDP in late 2000s, where almost 50 percent of total banking sector assets represented credit to firms. Similarly, Anzoategui et al. (2012) find that 59 percent of bank income is derived

\footnotetext{
${ }^{12}$ Also see www.archive.premier.gov.ru and Rabushka and Bernstam (2006) and Johnson (2009).
} 
from business lending. More importantly, Berglof and Lehmann (2009) show that the rapid expansion of bank finance played a positive role in Russia's economic growth, especially when banks extended their credit maturity date (to above one year) to enterprises.

In summary, we have argued that the reforms introduced by the Putin regime in the energy sector worked to enhance the flow of investment funds to the corporate sector. Thus an increase in energy-sector rents should be positively correlated with the improved long-term performance of firms. The caveat is, of course, that the employment of such funds are productively utilized and not siphoned off at the corporate level through asset-stripping, or more subtly applied to shorterthan-optimal investment projects. In addition, after the banking reforms, we should expect a strong positive relationship between the level of bank loans and firm long-term performance. We should also expect firms to enjoy higher long-term performance when a financial institution is present in its ownership structure as this will signal a continued availability of subsidized investment funds.

Finally, Vanteeva and Hickson (2012) argue that direct state involvement in the corporate governance of the individual firm receiving subsidized investments should also be positively correlated with firm long-term performance. Therefore, the presence of even partially-stateowned banks in firm shareholder structure should have an additional positive effect on firm longterm performance. The present use of the state banking system is consistent with a historical pattern of Russian financial intermediation (Kirdina and Vernikov, 2013) and it is fundamentally similar to the strategy of its late-nineteenth century tsarist ancestor, which is has been held to be a stereotypical model for Gerschenkron's 'catch up theory'. The obvious caveat here is that the state strategy is one of picking winners, that is, it is able to copy more advanced technologies of Western economies. 


\section{Methodology}

\subsection{Data sources}

Our main focus is to test the effectiveness of the reforms initiated by the early Putin regime which dramatically reversed the earlier 'laissez faire' policies of the 1990s, particularly those policies which led to the re-introduction of state co-ownership of natural resource, banking and other major Russian corporations. Specifically, we test the impact of the explicit reforms relating to the changes in the energy sector that facilitated the rents flowing to the state and the effectiveness of the banking and financial reforms that allowed the channelling of funds to the corporate sector. Consequently, our sample period includes the introduction of the above initiatives and ends the last full year before Putin's first tenure officially ended in May of 2008. ${ }^{13}$

Our dataset draws on hand-collected firm-specific information drawn from SKRIN and from the Russian Trading System stock exchange (RTS) from the beginning of 1998 through the end of 2007. Meaningful corporate-level data did not become available until 1998, though the RTS was founded in 1995. However, we end our sample period in 2007, which is the last full year of the first Putin tenure, and the year preceding the severe adverse effects on the Russian economy of the 2008 world financial crisis. Consequently, this year should provide a good terminal point in order to access the effectiveness of regime's reforms.

RTS was one of Russia's leading stock exchanges between 1995 and $2011 .{ }^{14}$ Its index was based on the 50 most liquid and capitalized Russia's companies, accounting for 85 percent of total market capitalization. Over the 1998-2007 period the number of companies trading on the RTS

\footnotetext{
${ }^{13}$ We also wish to minimize the effect of the 2008 global financial crisis on our findings.

${ }^{14}$ RTS merged with MICEX in 2011 to create Moscow Exchange.
} 
increased from approximately 150 to slightly over 400 . However, due to missing and incomplete data, our final dataset is composed of 2,036 firm-year observations. The financial information we compile on RTS-listed corporations includes annual key financial indicators, such as market capitalization figures, share prices and key balance sheet information. We also have detailed ownership data and other firm-specific information. Our primary data source is SKRIN database, which was founded by shareholders of the National Association of Securities Market Participants. SKRIN database makes available public companies' annual and quarterly reports in their original format from 1998 onwards. In addition, we also use RTS records and individual companies' websites.

\subsection{Definition of variables}

For our analysis, we chose to concentrate on long-term corporate performance rather than corporate short-term profit. For this purpose we apply two measures of Tobin's Q, which is broadly defined as 'the ratio of the market value of the firm's assets relative to the replacement cost of the firm's assets' (Wolfe, 2003:156). As firm's asset market value and asset replacement cost are not directly accessible from company accounts, we employ two common proxies which are frequently employed as proxies for Tobin's Q. Following Fama and French (2005), Chen et al., (2005) and Aggarwal and Samwick, (2006), our first proxy, denoted by TQ1, is defined as the sum of the book value of debt and the market value of equity, divided by total assets. This variable is able to capture any amount by which the market value of a firm may be above its book value (especially over the longer-term period). Following the work of Chung and Pruitt (1994), our second proxy, denoted by TQ2, is defined as the market value of all shares plus the book value of long term debt and the difference between current liabilities and current assets, all 
divided by the total value of firm's assets. So compared to TQ1, the latter measure takes into account any additional book value, which is attributable to a firm's short-term operations.

Berglof and Lehmann (2009) argue that long-term firm performance depends crucially on the availability of longer-term credit. Our focus is to gauge any positive effect on firm long-term performance that may be attributable to long-term loans, which in our case are overwhelmingly in the form of bank debt with a maturity greater than one year. To capture this effect over our sample period, following Miwa and Ramseyer (2002), we compute book value of long-term bank loans for each firm over its total assets. As we suspect that the level of bank loans closely corresponds to the level of subsidized funds (Rabushka and Bernstam, 2006), we can assume that the magnitude of bank loans channelled to a firm is positively correlated with its long-run performance.

Miwa and Ramseyer (2002) argue that firms with a financial-institution shareholder presence enjoy easier access to a steady stream of lower-cost loans. ${ }^{15}$ Such an advantage for firms should also lead to enhanced longer-term performance. Consequently, we include a dummy variable taking on a value of 1 if a particular firm has such a financial-institution as one of its major shareholders and 0 otherwise. ${ }^{16}$ However, in Russia it is important to recognize the intricate inter-relationship between state authorities and the success of particular companies in attaining subsidized investment finds. Therefore, we include a dummy variable, taking on the value of 1 and 0 otherwise, if a state or partially-state-owned financial intermediary is a major shareholder

\footnotetext{
${ }^{15}$ Also see Havrylchyk (2004).

${ }^{16}$ Key shareholders were identified from company reports. Although reports disclose information on all shareholders owning more than 5 percent of capital, we find that Russian corporate ownership is extremely concentrated, and the average fraction of capital owned by a major shareholder is 50 percent, while no financial institution owns less than 10 percent of capital.
} 
of a firm. ${ }^{17}$ If state-financial-institution-representation variable on corporate boards serves to better assure that loans are appropriately allocated, which is particularly important when loans are applied to large and lumpy investments as is often the case with longer-term projects, then the state-bank presence should greatly improve longer-run firm performance. On the other hand, if the presence of a state or partially-state-owned financial institution on corporate boards is simply a consequence of political patronage, then such loans should at best have only a negligible effect on firm long-term performance.

We also include several control variables that could influence firm long-term corporate performance. First, we include a firm size control variable. Following the method of Salancik and Pfeffer (1980), Berger and Ofek (1995) and Faccio et al. (2001), we use the natural log of total assets. ${ }^{18}$ To capture any possible effect due to firm profitability, we include the variable defined as net profit before interest and taxes, divided by sales (Machin and Van Reenen 1993; Schranz 1993; and Loughran and Ritter 1997). To account for any long-term effect on our firmperformance measure, we include a dummy variable, taking the value of 1 and 0 otherwise, if a corporation had existed prior to the economic restructuring policy of the 1990s. This also indicates that the firm was a former Soviet enterprise.

To account for any effect on long-term performance due to ownership concentration, we include a proxy defined as the percentage of capital owned by the largest shareholder. It appears that

\footnotetext{
${ }^{17}$ As the state can generally subsidize interest rates on loans obtained from commercial banks, we should not expect to find a substantial differences between the 'borrowing' effect of wholly and partially state-owned and private financial institutions, and state ownership may perhaps correspond to a substitute monitoring device (Analytical Report on Cooperative Sector in Russia and the Implementation of the ILO Recommendation No. 193, in the Development of Different Russian Cooperative Trends, 2009).

${ }^{18}$ The natural logarithm is commonly employed when the reported results are in the form of percentages. It is particularly useful when there exists a large spread of values, such as firm size, in order for the values of the variables to be more evenly distributed.
} 
Russian firms tend to have highly concentrated ownership structures, with a 50 percent stake on average held by the largest investor. As rising world oil prices during this period are widely believed to have had a significant positive effect on Russia's corporate sector, we introduce an oil price variable. However, we are more interested in whether any fortuitous earnings from rising oil prices actually generate positive cross effect on firms located in other industries, or whether the energy sector solely enjoyed this windfall. Therefore, we include an energy sector dummy variable, taking the value of 1 if the firm is located in the energy sector and 0 otherwise. Table 1 below offers a summary description of variables used in the regression analysis.

[insert Table 1 here]

\section{Findings}

\subsection{Descriptive statistics}

Table 2 reports some summary statistics over our sample period. It is divided into three subperiods: Period A spans 1998-1999, Period B spans 2000-2003 and Period C spans 2004-2007. These periods generally coincide respectively, the end of the Yeltsin era, the formative years of the successor Putin regime and the later years of first Putin regime when the institutional reforms discussed above have had more time to mature. We note that Tobin's Q1 rose sharply from 0.357 in the first period to 1.335 in the last period, suggesting an overall dramatic improvement of 
firms' long-term performance. ${ }^{19}$ Table 2 also indicates higher profitability ratios over the period, demonstrating a consistent strengthening of the country's corporate sector.

From the table, we can see that long-term debt as a proportion of overall corporate capital structure increased rapidly: the mean long-term debt increased from 0.033 in period A to 0.084 in period C. We also note a steady increase in company size, which is consistent with the willingness of Russian firms to increasingly undertake large investments. Finally, the table shows that ownership concentration mean increased from approximately 41 percent to 53 percent over the given time period.

[insert Table 2 here]

\subsection{The role of subsidized loans}

The dataset is an unbalanced panel data. Econometric tests suggest that a random effects model serves as the most effective tool to test the relationship between firms' Tobin's $Q$ and independent variables. However, as a robustness check, we apply both random and fixed effects models. ${ }^{20}$ A random effects model allows some omitted variables to vary across time, and others across entities, which is particularly important given the nature of this study. ${ }^{21}$ In comparison, a fixed effects model picks up a specific-firm effect.

Our regression takes the following form:

\footnotetext{
${ }^{19}$ We primarily introduce TQ2 measure as a robustness check and therefore do not include it in the descriptive statistics.

20 The Hausman test indicated that the null hypothesis of both estimation methods yielding similar coefficients was not rejected, therefore the random effects model was used as it produced more efficient estimators.

${ }^{21}$ As random effects model does not exclude the possibility of autocorrelation, we employed the Wooldridge (2002) test for first order autocorrelation. We consequently adjusted the model to allow estimation of a linear model with AR(1) disturbance ( in line with Cantarero and Lago-Penas, 2010).
} 
$\mathrm{Y}_{\mathrm{it}}=\beta_{0}+\beta_{1} \mathrm{X}_{1 \mathrm{it}}+\beta_{2} \mathrm{X}_{2 \mathrm{it}}+\beta_{3} \mathrm{X}_{3 \mathrm{it}}+\varepsilon_{\mathrm{it}}$

As mentioned above, our two proxies for Tobin's Q serve as our dependent variable, while our key variables of interest are long-term bank loans and the presence of a financial and state financial institution in firm shareholder structure. The remaining variables act as control variables.

Table 3 presents results from our regression analysis. We employ a Generalised Least Squares approach (random effects model, the results of which are reported in columns 1 and 2). We also employ a Generalised Method of Moments (GMM) approach in order to deal with endogeneity problems. ${ }^{22}$ These results are reported in columns 3 and 4 . From the table we can see that bank loans have a large positive effect on Tobin's Q. The variable has a coefficient of 2.379 and 1.408 in Columns 1 and 2, respectively, and a coefficient of 2.614 and 1.596 in columns 3 and 4 . The variable is also statistically significant at one percent level in all regressions. These strong results lend support to the view that larger flows of long-term subsidized debt produce a higher-longterm performance rate. Though, following Jensen (1986) it might be argued that high-debt levels serve as a monitoring tool through which long-term corporate performance can be enhanced. However, this argument may be more suited to more sophisticated capital markets, where large amounts of private corporate debt instruments are frequently traded. This is not a good description of the Russian financial markets, particularly during our sample period. ${ }^{23}$ Our results are more consistent with Kirdina and Vernikov (2013) hypothesis, who argue that the state has been traditionally involved in channelling funds to investment projects, as well as contributing to liquidity creation in Russia.

\footnotetext{
${ }^{22}$ We employ Arellano-Bond approach.

${ }^{23}$ See Alphonse (2006).
} 
[insert Table 3 here]

From the table we cannot clearly determine the effect of firm size on its long-term performance. However, the findings in column 3 and 4 suggest that firm size has a slight negative effect on Tobin's Q. Perhaps it can be argued that while company assets can generate higher earnings, they can also be subject to higher hold-up costs in an economy fraught with a weak property rights system.

Several past studies find a positive effect on firm long-term performance due to enhanced bookvalue profitability. Higher book-value profitability is typically associated with positive earnings announcements (Barberis et al., 1998; Daniel et al., 1998). In our case, we can see from the table that the effect of book-value profitability is very small and the variable is statistically significant in columns 3 and 4 only. Thus there appears to be no clear strong relationship between firm profitability and its Tobin's Q. Our results agree with many other studies, which concentrate on developing economies. Typically, such studies fail to find any significant positive effect from positive earnings announcements on Tobin’s Q proxies (DeFond et al., 2007).

Our findings also suggest that the degree of ownership concentration, which are significant at one percent significance level, has only a slightly positive effect on firm Tobin's Q. For example, the magnitude of variable coefficient ranges from 0.007 to 0.012 . Though our results are generally consistent with findings on other developing economies (Joh, 2003), it is important to recall that Russian companies have high ownership concentration ratios. Consequently, in the Russian case at least, the positive effect on Tobin' Q may be a consequence of ownership type rather than the concentration of capital ownership per se. 
Finally, the results show that firm Tobin's Q is adversely affected by firm longevity in the first two columns. ${ }^{24}$ The longevity parameter estimate is both large and significant. Such findings may at first appear unsurprising, as 'old' firms tend to exhaust their growth opportunities (Evans, 1987a, 1987b; Variyam and Kraybill, 1992). However, over the sample period, many 'old' Russian enterprises received substantial investment funds. This phenomenon can be rationalized by the fact that the longer-lived firm dummy may be have been adversely impacted by the earlier unsuccessful privatization initiative.

As it is widely accepted that rising oil prices had a significant impact on the Russian economy, we introduce the oil price variable, which acts as a macroeconomic variable, into our regression (columns 1 and 2, Table 4). Unsurprisingly, with average coefficient value of 1.268, the variable is large in magnitude, and it is statistically significant at one percent level. Nevertheless, we also note that the inclusion of this variable in our regression does not lead to alternative results produced for the key variable, in that bank loan coefficient is still large in magnitude and statistically significant at 1-5 percent level.

We are interested in the extent of transfers of natural resource rents marshalled into other economic sectors, and in comparing the long-term performance of energy-sector firms with that of firms located in other industries. Figure 1 shows that the Russia's energy sector firms have a high value, evidences by a Tobin's Q rising rapidly from 2000 through to 2006-2007. Yet, from Figure 2 we can see over the period that there is also an increasing discrepancy between energy firms' revenues and their final profits over the period. ${ }^{25}$ This is particularly evident during the

\footnotetext{
${ }^{24}$ Firm longevity variable is dropped from the regression output due to fixed effects being omitted from ArellanoBond estimation in columns 3 and 4.

${ }^{25}$ We do not have complete profit data for 1998.
} 
early Putin regime years, where rapidly increasing sales were combined with falling profits. Such a widening 'gap' infers that an extensive proportion of gains were at that time being re-directed to other important industries, consistent with the government's stated aim to broaden Russia's overall economic base (Butt et al., 2008).

[insert Figure 1 and Figure 2 here]

Columns 3 and 4 in Table 4 report our findings after we have included an energy sector dummy variable in the regressions. From the table we can see that the energy sector dummy is insignificant, indicating that energy firms do not necessarily enjoy higher Tobin's Q over firms located in other industries. ${ }^{26}$ Thus, it appears that energy sector firms were unable to inevitably capture increasing economic rents generated by rising world prices of oil and gas during this period, which is consistent with the state's objectives to collect and re-distribute energy profits to other sectors (Locatelli, 2006).

[insert Table 4 here]

\subsection{The role of emerging financial institutions}

In this paper we argue that Russian financial institutions primarily perform as conduits for statesponsored loans to chosen firms in preferred industries. Consequently, we are interested in whether a firm enjoys a stable and favorable access to a flow of subsidized funds. As noted above, the presence of a prominent state-financial institution, rather than simply indicating political patronage, might subject a firm to central-state monitoring to better assure a more appropriate allocation of its investment portfolio. Table 5 lists the number of financial

\footnotetext{
${ }^{26}$ Note that private investors do not face expropriation as the energy firm dummy does not have a negative impact on Tobin's Q.
} 
institutions registered as firms' major shareholder. It shows that this number increased from 12 in 1998 to 98 in 2007, with the number of state financial institutions exhibiting a continuous upward trend.

There is strong evidence in other economies that the presence of a financial institution on shareholder boards produces a positive effect on corporate value. This is particularly the case in countries (notably Germany and Japan), where financial intermediaries with large equity holdings play a significant corporate governance role. For example, Gorton and Schmid (2000) find a positive relationship between bank control rights stemming from equity ownership and improved firm performance in Germany, and Thomsen and Pedersen (2000) find that European firms, with strong ownership ties to financial institutions, as measured by market-to-book ratios, also tend to have higher shareholder value. Claessens et al. (1997) examine a voucher privatization scheme in Czech Republic. They find that ownership stemming from banksponsored funds also generates higher corporate profit. But the above comparisons may not be relevant in the Russian case because the state has an overwhelming grip on the financial sector, as noted above. Nevertheless, the relationship remains of interest, and we expect a positive effect on long-term performance when we find a financial-intermediary presence on corporate boards.

[insert Table 5 here]

Table 6 reports our results. As expected, the presence of a financial institution on firm shareholder board has a positive effect on firm long-term performance, where the variable coefficient has an average value of 0.228 , with a statistical significance ranging between the 1 and 10 percent. More importantly, Table 7 shows that the presence of a state-financial institution has an even more dramatic impact on firm Tobin's Q, where this variable's coefficient has a 
value range of 0.236 to 0.506 with increased level of significance. ${ }^{27}$ These results support our hypothesis that financial intermediaries act as conduits for state-sponsored loans to industry, but perhaps more importantly, support our view that state-financial institutions perform a positive role in enhancing corporate performance. Our findings are also consistent with Kirdina and Vernikov (2013), who believe that state banks' lending generates positive financial results.

\section{[insert Tables 6 and 7 here]}

\subsection{Robustness checks}

As we stated above, although the Hausman test suggests that random effects model is appropriate for our study, we also employ fixed effects model as a robustness check. The latter controls for the possibility that companies selected may be favoured by financial institutions or the central state. We report our results in Table 8. As is evidenced by the fact that the magnitude of all variables has increased, it can be seen that, if anything, the presence of a financial institution or a state-owned financial institution shareholder has an even larger effect on firm long-term performance. The magnitude of the bank loan variable coefficient has also increased to an average of 2.731. We also note a more pronounced negative effect of the size variable and a slightly increased positive effect of ownership concentration variable. Finally, we can see that Rsquared values have declined, which suggests that the model has a poorer fit. Overall, we show that our results are robust, and support the hypothesis that during this period the Russian state was successful in directing and monitoring subsidized investment funds for the purpose of enhanced corporate development.

[insert Table 8 here]

\footnotetext{
${ }^{27}$ When we applied the difference of means test we determined that the two means are significantly different from each other at 1 percent significance level.
} 


\section{Summary and conclusion}

This paper looks at possible reasons for the reversal of fortune enjoyed by Russian corporations from the turn of the millennium to the end of the sample period in 2007. We argue that there is a strong parallel between the corporate policies of the current regime and the tsarist regime during the end of the nineteenth century to World War I. Both periods are examples of Gerschenkron's catch-up theory. We argue that the later was necessary due to a high propensity to asset-strip company assets. Consequently, state control over the banking sector and thereby control over the flow of subsidized investment funds is a necessary second-best policy response when effective investor protection laws are absent.

Our finding agree with the typical view that the corporate recovery in Russia during our sample period is in large part attributable to fortuitous improved terms of trade earnings due to higher world oil prices. But we find that this explanation is incomplete as it fails to answer why the flow of funds from the energy sector, in contrast to the earlier period, was able to be successfully utilized at the corporate level. We also find that in our sample period the regime was able to capture most of the rents stemming from the energy sector. As we said before, this was accomplished by the central state, under the Subsoil Act, becoming the sole supplier of patents granting extraction rights. It also passed other laws which enhanced its bargaining power over both foreign and domestic extraction companies.

We also find that after the banking system was substantially reformed and brought under central state control, either through direct ownership or through other means, it was able to more successfully channel funds to targeted investment projects. Our results show that the presence of bank loans has a strong effect on firm long-term performance. For example, we pick up a 
positive effect of financial institution shareholder, which can signal of a continuous flow of subsidized loans. Furthermore, this effect is stronger if financial institution is partially or wholly state-owned, and state co-ownership appears to act as an additional monitoring mechanism against the diversion of funds.

Our analysis above recognizes the historical role of the Russian state in forcing both the path and speed of the economy's industrialization. The industrializing impetus of the present regime directs the pattern of industrialization to politically favored industrial sectors with subsidies gleaned from natural-resource export earnings rather than at the expense of agriculture, as was the case in the late Tsarist and Stalinist eras. But as the present Russian economy also lacks a free market system, so it may similarly suffer from allocational inefficiencies. As Gerschenkron's catch-up hypothesis allows technology to be easily borrowed under a free market when the necessary prerequisite institutions have evolved, the question is, can such institutions in Russia eventually evolve? Other developing economies have managed to do so successfully. Gerschenkron, as noted above, believed that a large motivation of the Tsarist and Stalinist regimes was to bolster their military capability. He also believed that this consideration, above all else, had, when combined with economic backwardness, undermined the possibility of a Western-style economy. Perhaps a similar rationale lies behind the present regime's motivation for its version of state-directed industrialization. If so, this would provide an answer as to why Russia fits neatly into Kirdina and Vernikov (2013) institutional matrix as an ideal example of a non-market economy. 
The path of Russian corporate and economic progress depends on the answer to this question. Thus a future study on which industries are most favored would help. However, we would also like to extend our study to encompass a more comprehensive understanding of the nature of the Russian corporation, particularly to collect more detailed knowledge about their use of other funds, and their dividend pay-out policies. Finally, there is the issue of political stability of the coalition of oligarchs. These extensions are all the more important given the more recent swings in the business cycle. 


\section{Bibliography}

Adachi, Y., 2009. Subsoil Law reform in Russia under Putin administration. Europe-Asia Studies 61 (8), 1393-1414.

Akhtyrov, A., 2003. Russian oil oligarchs always fight. Pravda, 25 January.

Aggarwal, R.K., Samwick, A.A., 2006. Empire-builders and shirkers: investment, firm performance, and managerial incentives. Journal of Corporate Finance 12(3), 489-515.

Alchian, A.A., Woodward, S., 1988. The firm is dead; long live the firm: a review of Oliver E. Williamson's the Economic Institutions of Capitalism. Journal of Economic Literature, 26(1), 65-79.

Alphonse, P., J. Ducret, Severin, E., 2006. When trade credit facilitates access to bank finance: evidence from US small business data. EFMA 2004 Basel Meeting Paper.

Anzoategui, D., Soledad-Martinez-Peria, M., Melecky, M., 2012. Bank competition in Russia: an examination of different levels of aggregation. Emerging Markets Review 13 (1), 42-57.

Barberis, N., Shleifer, A., Vishny, R., 1998. A model of investor sentiment. Journal of Financial Economics 49(3), 307-343.

Barnes, A., 2007. Industrial property in Russia: the return of the state and a focus on oil. SAIS Review, 27 (2), 47-62.

Berger, P.G., Ofek, E., 1995. Diversification's effect on firm value. Journal of Financial Economics 37(1), 39-65.

Berglof, E., Bolton, P., 2002. The great divide and beyond: financial architecture in transition. Journal of Economic Perspectives, 16 (1), 77-100.

Berglof, E., Lehmann, A., 2009. Sustaining Russia's growth: the role of financial reform. Journal of Comparative Economics 37 (2), 198-206.

Bhattacharya, U., 2003. The optimal design of Ponzi schemes in finite economies. Journal of Financial Intermediation, 12 (1), 2-24.

Black, B.S., Kraakman, R, Tarassova, A.S., 2000: Russian privatisation and corporate governance: what went wrong?. Stanford Law Review 52, 1731-1808.

Butt, S., Shivdasani, A., Stendevad, C., Wyman, A., 2008. Sovereign wealth funds: a growing global force in corporate finance. Journal of Applied Corporate Finance, 20 (1),73-83.

Buyske, G., 2007. Banking on Small Business: Microfinance in Contemporary Russia. Cornell University Press, Ithaca. 
Cantarero, D., Lago-Penas, S., 2010. The determinants of healthcare expenditure: a reexamination. Applied Economic Letters 17 (7), 723-726.

Chandrasekhar, C.P., 2005. Alexander Gerschenkron and late industrialisation, in: Jomo, K.S. (Eds.), The Pioneers of Development Economics. Zed Books Ltd., London, pp.181-190.

Chen, H., Frank, M.Z., Wu, O.Q., 2005. What actually happened to the inventories of American companies between 1981 and 2000?. Management Science 51(7), 1015-1031.

Chernykh, L., Cole, R.A., 2010. Does deposit insurance improve financial intermediation? Evidence from the Russian experiment. Journal of Banking and Finance, 35 (2), 388-402.

Chung, K.H., Pruitt, S.W., 1994. A simple approximation of Tobin's Q. Financial Management 23(3), 70-74.

Claessens, S., Djankov, S., Pohl, G., 1997. Ownership and corporate governance: evidence from the Czech Republic. Policy Research Working Paper Series 1737, The World Bank.

Cooper, W.H., 2001. Russia's economic performance: entering the $21^{\text {st }}$ century. Russia's Uncertain Economic Future, Compendium of Papers submitted to the Joint Economic Committee Congress of the United States.

Crisp, O., 1953. Russian financial policy and the gold standard at the end of the nineteenth century. The Economic History Review, 6 (2), 156-172.

Crisp, O., 1973: Review: the economic history of pre-reform Russia. The Slavonic and East European Review, 51 (125), 582-593.

Crisp, O., 1991. European industrialisation: Russia, in: Sylla, R., Toniolo, G. (Eds.), Patters of European Industrialisation During the Nineteenth Century. Routledge, London, pp. 248-268.

Daniel, K., Hirshleifer, D., Subrahmanyam, A., 1998. Investor psychology and security market under-and overreactions. The Journal of Finance 53(6), 1839-1885.

DeFond, M., Hung, M., Trezevant, R., 2007. Investor protection and the information content of annual earnings announcements: international evidence. Journal of Accounting and Economics 43(1), 37-67.

Denezhno-kreditnaya politika segodnya i zavtra: nyzhna li smena akcentov. Organizaciya Prodazh Bankkovskih Produktov, No.1, 2007.

Dmitriev, E., 2004. Gluboko kapaet. Profil, 26 July.

Doh, J., Teegen, H., Mudambi, R., 2004. Balancing private and state ownership in emerging markets' telecommunications infrastructure: country, industry, and firm influences. Journal of International Business Studies 35(3), 233-250. 
Drummond, I.M., 1976. The Russian gold standard, 1897-1914. The Journal of Economic History, 36 (4), 663-688.

Dugger, W., 1990. The new institutionalism: new but not institutionalist. Journal of Economic Issues 24(2), 423-431.

Ehrstedt, S., Vahtra, P., 2008. Russian energy investment in Europe. Electronic Publications of Pan-European Institute 4/2008, online http://www.tse.fi/FI/yksikot/erillislaitokset/pei/Documents/Julkaisut/Ehrstedt_Vahtra_42008.pdf

Ericson, R.E., 2009. The Russian economy in 2008: testing the "market economy". Post-Soviet Affairs, 25 (3), 209-231.

Erochkine, V., Erochkine, P., 2006. Russia's Oil Industry: Current Problems and Future Trends. The Centre for Global Studies, Westminster, London.

Evans, D. S., 1987a. Tests of alternative theories of firm growth. The Journal of Political Economy 95(4), 657-674.

Evans, D. S., 1987b. The relationship between firm growth, size, and age: estimates for 100 manufacturing industries. The Journal of Industrial Economics 35(4), 567-581.

Faccio, M., Lang, L.H.P., Young, L., 2001. Dividends and expropriation. American Economic Review 91(1), 54-78.

Falkus, M., 2008. Aspects of Russian industrialisation before the First World War. Australian Journal of Politics \& History, 12(3), 330-340.

Fama, E.F. and French, K.R., 2005. Financing decisions: who issues stock? Journal of Financial Economics 76(3), 549-582.

Fungacova, Z., Solanko, L., 2009. Has banks' financial intermediation improved in Russia?. BOFIT Discussion Papers 8, Bank of Finland, Institute for Economies in Transition.

Fungacova, Z., Weill, L., 2009. How market power influences bank failures: evidence from Russia. BOFIT Discussion Papers 12, Bank of Finland, Institute for Economies in Transition.

Gaddy, C.G., 2004. Perspectives on the potential of Russian oil. Eurasian Geography and Economics 45 (5), 346-351.

Gaddy, C.G., Ickes, B.W., 2005. Resource rents and the Russian economy. Eurasian Geography and Economics 46 (8), 559-583.

Gaddy, C.G., Ickes, B.W., 2009. Russia's declining oil production: managing price risk and rent addiction. Eurasian Geography and Economics 50 (1), 1-13. 
Gatrell, P., 1994. Government, Industry and Rearmament in Russia, 1900-1914. Cambridge University Press, Cambridge.

Gerschenkron, A., 1962. Economic Backwardness in Historical Perspective: A Book of Essays. Harvard University Press, Cambridge, M.A.

Geyer, D., 1987. Russian Imperialism: The Interaction of Domestic and Foreign Policy 18601914. Berg Publishers Ltd., Leamington Spa.

Gidadhubli, R.G., Kumar, R.S., 1999. Causes and consequences of money laundering in Russia. Economic and Political Weekly, 34 (48), 3395-3399.

Gnezditskaia, A. 2003. Russian banks' profit strategies: the evidence from various types of banks. Communist and Post-Communist Studies, 36 (2), 163-191.

Gorton, G., Schmid, F.A., 2000. Universal banking and the performance of German firms. Journal of Financial Economics, 58 (1-2), 29-80.

Gregory, P.R., 1991. The role of the state in promoting economic development: the Russian case and its general implications, in: Sylla, R., Toniolo, G. (Eds.), Patters of European Industrialisation During the Nineteenth Century. Routledge, London, pp. 64-79.

Guriev, S., Rachinsky, A., 2005. The role of the oligarchs in Russian capitalism. Journal of Economic Perspectives 19 (1), 131-150.

Hanson, P., 2007. The Russian economic puzzle: going forward, backwards or sideways?. International Affairs, 83 (5), 869-889.

Hanson, P., 2009. The resistible rise of state control in the Russian oil industry. Eurasian Geography and Economics, 50 (1), 14-27.

Hare, P., M.E. Schaffer, Shabunina, A., 2004. The great transformation: Russia's return to the world economy. Discussion Paper 2004/01, Centre for Economic Reform and Transformation.

Harris, J., 2009. Statist globalization in China, Russia and the Golf States. Perspectives on Global Development and Technology 9 (2/3), 139-163.

Havrylchyk, O., 2004. Rapid loan growth in Russia: a lending boom or a permanent financial deepening?. MPRA Paper No. 20997, Economic and Financial Affairs European Commission.

Heinrich, A., Kusznir, J., Pleines, H., (2002). Foreign investment and national interests in the Russian oil and gas industry. Post-Communist Economies 14 (4), 495-507.

Hill, F., Fee, F., 2002. Fuelling the future: the prospects for Russian oil and gas. Demokratizatsiya, 10 (4), 462-487. 
Hoff, K., Stiglitz, J.E., 2004. After the big bang? Obstacles to the emergence of the rule of law in post-communist societies. The American Economic Review 94(3). 753-763.

Hoffman, D.E., 2002. The Oligarchs: Wealth and Power in the New Russia. Public Affairs: New York.

Hogan, H., 1993: Forging Revolution: Metalworkers, Managers, and the State in St. Petersburg 1890-1914. Indiana University Press, Bloomington and Indianapolis.

International labour organization report on cooperative sector in Russia and the implementation of the ILO recommendation No. 193., 2009. The Development of Different Russian Cooperative Trends, ILO Subregional Office for Eastern Europe and Central Asia.

Jensen, M., 1986: The agency costs of free cash flow: corporate finance and takeovers. American Economic Review 76 (2), 323-330.

Johnson, D., 2009. Russia's anti-crisis package to hit 12\% of GDP in 2009 - Putin. Johnson's

Russia List, online

http://www.cdi.org/Russia/johnson/2009-50-22.cfm

Joh, S.W., 2003. Corporate governance and firm profitability: evidence from Korea before the economic crisis. Journal of Financial Economics 68 (2), 287-322.

Johnson, J., 2004. Does Central Bank independence matter in Russia?. Ponars Policy Memo, Program on the New Approaches to Russian Security, McGill University.

Kak osuschestvlyaetsya predostavleniye budzhetnih sredstv $\mathrm{v}$ forme budzhetnoi subsidii $\mathrm{i}$ subvencii. Reform No. 607-PP, Russia.

Kalyuzhnova, E., Nygaard, C., 2009. Oil, credit growth and state owned financial intermediaries in Russia and Kazakhstan. The Centre for Euro-Asian Studies, The University of Reading.

Kanel, D. (1974). Property and economic power as issues in institutional economics. Journal of Economic Issues 8(4), 827-840.

Kirdina, S., Vernikov, A., 2013. eEvolution of the banking system in the Russian context: an institutional view. Journal of Economic Issues 47 (2), 473-481.

Laeven, L., 2001. Insider lending and bank ownership: the case of Russia. Journal of Comparative Economics, 29 (2), 207-229.

Ledeneva, A., Shekshnia, S., 2011. Doing business in Russian regions: informal practices and anti-corruption strategies. Russie.Nei.Nisions No. 58, Russian/NIS Center.

Locatelli, C., 2006. The Russian oil industry between public and private governance: obstacles to international oil companies’ investment strategies. Energy Policy, 34 (9), 1075-1085. 
Loughran, T., Ritter, J.R., 1997. The operating performance of firms conducting seasoned equity offerings. The Journal of Finance 52(5), 1823-1850.

Machin, S., Van Reenen, J., 1993. Margins and the business cycle: evidence from UK manufacturing firms. The Journal of Industrial Economics 41(1), 29-50.

Macneil, I.R., 1980. Power, contract and the economic model. Journal of Economic Issues 14(4), 909-923.

McCloskey, D.N., 1991. Kinks, tools, spurts and substitutes: Gerschenkron's rhetoric of relative backwardness, in Sylla, R., Toniolo, G. (Eds.), Patters of European Industrialisation During the Nineteenth Century. Routledge, London, pp. 92-105.

Meyendorff, A., Snyder, E.A., 1997. Transactional structures of bank privatisation in Central Europe and Russia. Journal of Comparative Economics, 25 (1), 5-30.

Miller, M., 1967. The Economic Development of Russia 1905-1914. Routledge, London.

Miwa, Y., Ramseyer, J.M., 2002. Banks and economic growth: implications from Japanese history. Journal of Law and Economics 45, 127-164.

Nilsen, A., 2006. Russian capitalism. OCGG Economy Briefing No. 2. The Oxford Council on Good Governance.

Osipov, I., 2006. Towards regaining energy control: foreign investment, Kovykta project, and the rise of Gazprom (lessons learned). Center for Applied Business Research in Energy and Environment, University of Alberta School of Business.

Palermo, G., 2000. Economic power and the firm in new institutional economics: two conflicting problems. Journal of Economic Issues 34 (3), 573-601.

Parto, S., 2005. Economic activity and institutions: taking stock. Journal of Economic Issues 39 (1), 21-52.

Peresetsky, A.A., A.M. Karminsky, Golovan, S.V., 2007. Russian banks’ private deposit interest rates and market discipline. BOFIT Discussion Paper 2/207, Institute for Economies in Transition, Bank of Finland.

Peshkova, A., 2008. The effects of higher oil prices on the Russian economy”, Cognita, 17, 5-9.

Pistor, K., Spicer, A., 1997. Investment funds in mass privatization and beyond: evidence from Czech Republic and Russia, in: Lieberman, I.W., S. Nestor, Desai, D.M., (Eds.), Between State and Market: Mass Privatization in Transition Economies. World Bank Publications.

Rabochi deni - interview with Vladimir Putin. Sait Predsedatelya Pravitelstva Rossiiskoi Federacii V.V. Putina, 13 April 2008. 
Rabushka, A., Bernstam, M.S., 2006. China vs. Russia: international bankers run a natural experiment: comments, essays and speeches. Hoover Institution, Stanford University.

Rautava, J., 2004. The role of oil prices and the real exchange rate in Russia's economy - a cointegration approach. Journal of Comparative Economics, 32 (2), 315-327.

Reynolds, D.B. Kolodziej, M., 2007. Institutions and the supply of oil: a case study of Russia. Energy Policy, 35 (2), 939-949.

Rock, C.P., Solodkov, V., 2001. Monetary policies, banking, and trust in changing institutions: Russia's transition in the 1990s. Journal of Economic Issues 35(2), 451-458.

Sagers, M.J., 2006. The regional dimension of Russian oil production: is sustained recovery in prospect? Eurasian Geography and Economics 47(5), 505-545.

Salancik, G.R., Pfeffer, J., 1980. Effects of ownership and performance on executive tenure in U.S. corporations. The Academy of Management Journal 23(4), 653-664.

Scharf, S., 2006. Russia and the WTO: Reasons for the Delay in the Accession Process. Lightning Source UK Ltd., Milton Keynes.

Schranz, M., 1993. Takeovers improve firm performance: evidence from the banking industry. The Journal of Political Economy 101(2), 299-326.

Shakina, M., 2001. Russia's Sberbank turns 160. The Embassy of The Russian Federation in the Netherlands, Russian Diary $\backslash$ N49, online http://www.netherlands.mid.ru/dnev/eng/dnev2001e/dnev_49_e.html\#4

Smith, G.B.,1996. Reforming the Russian legal system. Cambridge University press.

Sonin, C., 2000. Inequality, property rights, and economic growth in transition economies: theory and Russian evidence. Working Paper No. 2K/02. EERC Research Network, Russia.

Spicer, A., Pyle, W., 2003. Institutions and the vicious circle of distrust in the Russian household deposit market 1992-1999. Working Paper No. 588, William Davidson Institute.

Strategicheskiye celi razvitiya strain. Budget Reform in Action, Budzhetnaya Politika, 20062008.

Styrin, K., 2005. "X-inefficiency, moral hazard, and bank failures. Final Report, Economics Education and Research Consortium, Russia and CIS.

Sutela, P., 2000. The financial crisis in Russia, in: Bisignano, J., W.C. Hunter, Kaufamn, G.G. (Eds.), Global Financial Crises: Lessons from Recent Events. Kluwer, Boston, pp. 63-73. 
Sutela, P., 2005. Did Putin's reforms catapult Russia to durable growth?. BOFIT No. 6, Institute for Economies in Transition, Bank of Finland.

Tabata, S., 2002. Russian revenues from oil and gas exports: flow and taxation. Eurasina Geography and Economics 43 (8), 610-627.

Thomsen, S., Pedersen, T., 2000. Ownership structure and economic performance in the largest European companies. Strategic Management Journal, 21 (6), 689-705.

Thomson, W., 2002. The present and future of banking reform, in: Lane, D., (Eds.), Russian Banking Evolution, Problems and Prospects. Edward Elgar, Cheltenham: pp. 56-78.

Tompkins, S.R., 1933. Witte as minister of finance, 1892-1903. The Slavonic and East European Review, 11, 590-606.

Vaaler, P.M., Schrage, B.N., 2009. Residual state ownership, policy stability and financial performance following strategic decisions by privatizing telecoms. Journal of International Business Studies 40, 621-641.

Vanteeva, N., Hickson, C., 2012. Whither corporate Russia?. Comparative Economic Studies 54(1), 173-201.

Variyam, J.N., Kraybill, D.S., 1992. Empirical evidence on determinants of firm growth. Economic Letters 38(1), 31-36.

Vdovichenko, A.G., Voronina, V.G., 2006. Monetary policy rules and their application in Russia. Research in International Business and Finance, 20 (2), 145-162.

Vernikov, A.V., 2007. Russia's banking sector transition: where to?. BOFIT Discussion Paper No. 5, Institute for Economies in Transition, Bank of Finland.

Vedev, A., 2008. Revising the quality of growth. Economic Monthly, Bank of Moscow online http://www.vedi.ru/bank_sys/bank2808_e.pdf

Vernikov, A., 2009. Russian banking: the state makes a comeback?. BOFIT Discussion Papers 24, Institute for Economies in Transition, Bank of Finland.

Vernikov, A., 2010. Direct and indirect state ownership on banks in Russia. MPRA Paper No. 21373.

Williamson, O.E., 1985. The Economic Institutions of Capitalism. The Free Press, New York.

Willis, H.P., 1897. Monetary reform in Russia. The Journal of Political Economy, 5, 277-315.

Wolfe, J., 2003. The Tobin's Q as a company performance indicator. Developments in Business Simulation and Experimental Learning, 30, 155-159. 
Wolosky, L.S., 2000. Putin’s plutocrat problem. Foreign Affairs, 79 (2), 18-31.

Wooldridge, J.M., 2002. Econometric Analysis of Cross Section and Panel Data. MIT Press, Cambridge, MA.

Yakovlev, E., Zhuravskaya, E., 2006. State capture: from Yeltsin to Putin. CEFIR Working Paper No. 94, Center for Economic and Financial Research. 


\section{Table 1. Definition of variables}

\begin{tabular}{|c|c|}
\hline Variable & Description \\
\hline \multirow[t]{2}{*}{ Tobin's Q } & $\begin{array}{l}\text { TQ1 }\left(\mathrm{V}_{\mathrm{t}}+\mathrm{LTD}_{\mathrm{t}}+\mathrm{STDt}\right) / \mathrm{A}_{\mathrm{t}} \text {. The market value of equity plus book value } \\
\text { of debt, divided by total assets (Fama and French, 2005; Chen et al., } \\
\text { 2005; Aggarwal and Samwick, 2006). }\end{array}$ \\
\hline & $\begin{array}{l}\left(\mathrm{V}_{t}+\mathrm{LTD}_{t}+\left(\mathrm{CA}_{t}-\mathrm{CL}_{t}\right)\right) / \mathrm{A}_{\mathrm{t}} \text {. The market value of equity plus book } \\
\text { value of long-term debt and the difference between current assets } \\
\text { and current liabilities, divided by total assets (Chung and Pruitt, } \\
\text { 1994). }\end{array}$ \\
\hline Bank loan & $\begin{array}{l}\mathrm{LTD}_{\mathrm{t}} / \mathrm{A}_{\mathrm{t}} \text {. The ratio of book value of long-term bank loans to total assets } \\
\text { (Miwa and Ramseyer, 2002). }\end{array}$ \\
\hline $\begin{array}{l}\text { Financial } \\
\text { institution }\end{array}$ & $\begin{array}{l}\text { Equals } 1 \text { if the firm has financial institution as its major shareholder; } 0 \\
\text { otherwise. }\end{array}$ \\
\hline $\begin{array}{l}\text { State financial } \\
\text { institution }\end{array}$ & $\begin{array}{l}\text { Equals } 1 \text { if the firm has wholly or partially state-owned financial institution as } \\
\text { its major shareholder; } 0 \text { otherwise. }\end{array}$ \\
\hline Size & $\begin{array}{l}\text { LnA }_{t} \text {. The natural log of total assets (Salancik and Pfeffer, 1980; Berger and } \\
\text { Ofek, 1995; Faccio et al., 2001). }\end{array}$ \\
\hline Profitability & $\begin{array}{l}E_{t} / \text { Sales}_{t} \text {. The ratio of earnings before interest and taxes to sales (Machin and } \\
\text { Van Reenen, 1993; Schranz, 1993; Loughran and Ritter, 1997). }\end{array}$ \\
\hline Firm longevity & Equals 1 if the firm had existed during the Soviet era; 0 otherwise. \\
\hline $\begin{array}{l}\text { Ownership } \\
\text { concentration }\end{array}$ & Fraction of capital owned by the largest shareholder, expressed in $\%$. \\
\hline Energy firm & Equals 1 if the firm belongs to the energy sector; 0 otherwise. \\
\hline Oil price & Natural log of world oil price.* \\
\hline
\end{tabular}

All financial data is expressed in thousands of Russian roubles.

* Oil prices were obtained from The New York Mercantile Exchange and British Petroleum websites. 
Table 2. Summary statistics for firms trading on RTS between 1998 and 2007

\begin{tabular}{|c|c|c|c|c|c|}
\hline Variable & No. of obs & Mean & $\begin{array}{l}\text { Standard } \\
\text { deviation }\end{array}$ & Min & Max \\
\hline \multicolumn{6}{|c|}{ Panel A: 1998-1999 } \\
\hline $\begin{array}{l}\text { Tobin's Q } \\
\left(\mathrm{V}_{\mathrm{t}}+\mathrm{LTD}_{\mathrm{t}}+\mathrm{STD}_{\mathrm{t}}\right) / \mathrm{A}_{\mathrm{t}}\end{array}$ & 165 & 0.357 & 0.490 & 0.003 & 3.644 \\
\hline Size $\left(\operatorname{LnA}_{t}\right)$ & 269 & 15.082 & 1.626 & 10.941 & 20.985 \\
\hline Long-term debt $\left(\mathrm{LTD}_{\mathrm{t}} / \mathrm{A}_{\mathrm{t}}\right)$ & 269 & 0.033 & 0.084 & 0.000 & 0.598 \\
\hline Profitability $\left(\mathrm{E}_{\mathrm{t}} /\right.$ Sales $\left._{\mathrm{t}}\right)$ & 139 & 0.080 & 0.429 & -0.119 & 0.805 \\
\hline Ownership concentration (\%) & 270 & 41.304 & 17.679 & 7.000 & 99.000 \\
\hline \multicolumn{6}{|c|}{ Panel B: 2000-2003 } \\
\hline $\begin{array}{l}\text { Tobin's Q } \\
\left(\mathrm{V}_{\mathrm{t}}+\mathrm{LTD}_{\mathrm{t}}+\mathrm{STD}_{\mathrm{t}}\right) / \mathrm{A}_{\mathrm{t}}\end{array}$ & 531 & 0.508 & 0.615 & 0.001 & 4.878 \\
\hline $\operatorname{Size}\left(\operatorname{LnA}_{t}\right)$ & 710 & 15.661 & 1.691 & 9.664 & 21.626 \\
\hline Long-term debt $\left(\mathrm{LTD}_{\mathrm{t}} / \mathrm{A}_{\mathrm{t}}\right)$ & 710 & 0.061 & 0.121 & 0.000 & 0.984 \\
\hline Profitability $\left(\mathrm{E}_{\mathrm{t}} / \mathrm{Sales}_{\mathrm{t}}\right)$ & 639 & 0.103 & 0.202 & -3.047 & 0.969 \\
\hline Ownership concentration (\%) & 696 & 45.185 & 17.889 & 6.000 & 99.000 \\
\hline \multicolumn{6}{|c|}{ Panel C: 2004-2007 } \\
\hline $\begin{array}{l}\text { Tobin's Q } \\
\left(\mathrm{V}_{\mathrm{t}}+\mathrm{LTD}_{\mathrm{t}}+\mathrm{STD}_{\mathrm{t}}\right) / \mathrm{A}_{\mathrm{t}}\end{array}$ & 670 & 1.335 & 1.289 & 0.001 & 14.320 \\
\hline $\operatorname{Size}\left(\operatorname{LnA}_{t}\right)$ & 829 & 15.944 & 1.994 & 9.083 & 22.291 \\
\hline Long-term debt $\left(\mathrm{LTD}_{\mathrm{t}} / \mathrm{A}_{\mathrm{t}}\right)$ & 827 & 0.084 & 0.135 & 0.000 & 0.943 \\
\hline Profitability $\left(\mathrm{E}_{\mathrm{t}} / \mathrm{Sales}_{\mathrm{t}}\right)$ & 732 & 0.125 & 0.489 & -2.936 & 0.988 \\
\hline Ownership concentration (\%) & 791 & 53.328 & 19.453 & 8.754 & 99.000 \\
\hline
\end{tabular}


Table 3. The effect of bank loans on firms' Tobin's Q

\begin{tabular}{lllll}
\hline Variable & TQ1 & TQ2 & TQ1 (GMM) & TQ2 (GMM) \\
\hline Bank loan & $2.379^{* * *}$ & $1.408^{* * *}$ & $2.614^{* * *}$ & $1.596^{* * *}$ \\
& $(0.394)$ & $(0.395)$ & $(0.259)$ & $(0.252)$ \\
Size & -0.006 & -0.010 & $-0.129^{* * *}$ & $-0.085^{* *}$ \\
& $(0.034)$ & $(0.034)$ & $(0.044)$ & $(0.042)$ \\
Profitability & 0.016 & -0.001 & $0.026^{* *}$ & $0.029^{* * *}$ \\
& $(0.014)$ & $(0.004)$ & $(0.011)$ & $(0.011)$ \\
Ownership & $0.012^{* * *}$ & $0.012^{* * *}$ & $0.008^{* * *}$ & $0.007^{* * *}$ \\
concentration & $(0.003)$ & $(0.003)$ & $(0.002)$ & $(0.002)$ \\
Firm longevity & $-0.820^{* * *}$ & $-0.828^{* * *}$ & & \\
TQ(L1) & $(0.156)$ & $(0.156)$ & & \\
& & & $0.346^{* * *}$ & $0.285^{* * *}$ \\
Constant & & & $(0.077)$ & $(0.093)$ \\
& $1.010^{*}$ & 0.673 & $1.881^{* *}$ & $1.455^{* *}$ \\
\hline No. of observations & $(0.551)$ & $(0.550)$ & $(0.923)$ & $(0.658)$ \\
R-squared & 1189 & 1189 & 780 & 780 \\
Wald chi squared value & 0.158 & 0.157 & & $190.26^{* * *}$ \\
\hline
\end{tabular}

$*, * *$ and $* * *$ denote significance at the 10,5 and 1 percent level, respectively 
Table 4. The effect of energy rents on firms' Tobin's Q

\begin{tabular}{|c|c|c|c|c|}
\hline Variable & TQ1 (1) & TQ2 (1) & TQ1 (2) & TQ2 (2) \\
\hline Bank loan & $\begin{array}{l}1.855^{* * * *} \\
(0.382)\end{array}$ & $\begin{array}{l}0.880^{* *} \\
(0.382)\end{array}$ & $\begin{array}{l}2.379 * * * \\
(0.394)\end{array}$ & $\begin{array}{l}1.407 * * \\
(0.395)\end{array}$ \\
\hline Size & $\begin{array}{l}-0.052 \\
(0.034)\end{array}$ & $\begin{array}{l}-0.036 \\
(0.033)\end{array}$ & $\begin{array}{l}-0.017 \\
(0.036)\end{array}$ & $\begin{array}{l}0.001 \\
(0.035)\end{array}$ \\
\hline Profitability & $\begin{array}{l}0.012 \\
(0.014)\end{array}$ & $\begin{array}{l}0.001 \\
(0.004)\end{array}$ & $\begin{array}{l}0.017 \\
(0.014)\end{array}$ & $\begin{array}{l}-0.001 \\
(0.004)\end{array}$ \\
\hline $\begin{array}{l}\text { Ownership } \\
\text { concentration }\end{array}$ & $\begin{array}{l}0.003 \\
(0.002)\end{array}$ & $\begin{array}{l}0.003 \\
(0.003)\end{array}$ & $\begin{array}{l}0.012 * * * \\
(0.003)\end{array}$ & $\begin{array}{l}0.012^{* *} \\
(0.003)\end{array}$ \\
\hline Firm longevity & $\begin{array}{l}-0.377 * * \\
(0.159)\end{array}$ & $\begin{array}{l}-0.386 * * \\
(0.157)\end{array}$ & $\begin{array}{l}-0.822 * * * \\
(0.157)\end{array}$ & $\begin{array}{l}-0.830 * * * \\
(0.156)\end{array}$ \\
\hline Oil price & $\begin{array}{l}1.252 * * * \\
(0.117)\end{array}$ & $\begin{array}{l}1.284 * * * \\
(0.116)\end{array}$ & & \\
\hline Energy sector & & & $\begin{array}{l}0.230 \\
(0.246)\end{array}$ & $\begin{array}{l}0.222 \\
(0.248)\end{array}$ \\
\hline Constant & $\begin{array}{l}-2.830^{* * *} \\
(1.337)\end{array}$ & $\begin{array}{l}-3.239 * * * \\
(0.643)\end{array}$ & $\begin{array}{l}1.149 * * \\
(0.570)\end{array}$ & $\begin{array}{l}0.804 \\
(0.569)\end{array}$ \\
\hline No. of observations & 1189 & 1189 & 1189 & 1189 \\
\hline R-squared & 0.164 & 0.161 & 0.159 & 0.159 \\
\hline Wald chi squared value & $240.25 * * *$ & $241.95 * * *$ & $224.11 * * *$ & $229.62 * * *$ \\
\hline
\end{tabular}


Table 5. Number and type of financial intermediaries registered as firms' major shareholder for companies trading on RTS during 1998-2007

\begin{tabular}{cccc}
\hline Year & $\begin{array}{c}\text { No. of firms with non- } \\
\text { state financial } \\
\text { intermediary as largest } \\
\text { shareholder }\end{array}$ & $\begin{array}{c}\text { No. of firms with state- } \\
\text { influenced financial } \\
\text { intermediary as largest } \\
\text { shareholder }\end{array}$ & $\begin{array}{c}\text { Total no. of firms with } \\
\text { financial intermediary } \\
\text { as largest shareholder }\end{array}$ \\
\hline 1998 & 11 & 1 & 12 \\
1999 & 18 & 5 & 23 \\
2000 & 26 & 8 & 34 \\
2001 & 28 & 14 & 42 \\
2002 & 35 & 13 & 48 \\
2003 & 53 & 19 & 72 \\
2004 & 60 & 17 & 77 \\
2005 & 57 & 20 & 87 \\
2006 & 51 & 36 & 98 \\
2007 & 49 & 49 & \\
\hline
\end{tabular}


Table 6. The effect of financial institution shareholder on firms' Tobin's Q

\begin{tabular}{|c|c|c|c|c|}
\hline Variable & TQ1 & TQ2 & TQ1 (GMM) & TQ2 (GMM) \\
\hline $\begin{array}{l}\text { Financial } \\
\text { institution }\end{array}$ & $\begin{array}{l}0.270^{* * *} \\
(0.115)\end{array}$ & $\begin{array}{l}0.314 * * * \\
(0.114)\end{array}$ & $\begin{array}{l}0.134 * \\
(0.070)\end{array}$ & $\begin{array}{l}0.192 * * * \\
(0.068)\end{array}$ \\
\hline Bank loan & $\begin{array}{l}2.416 * * * \\
(0.394)\end{array}$ & $\begin{array}{l}1.453 * * * \\
(0.395)\end{array}$ & $\begin{array}{l}2.568 * * * \\
(0.260)\end{array}$ & $\begin{array}{l}1.540 * * * \\
(0.251)\end{array}$ \\
\hline Size & $\begin{array}{l}-0.010 \\
(0.034)\end{array}$ & $\begin{array}{l}0.006 \\
(0.034)\end{array}$ & $\begin{array}{l}-0.142 * * * \\
(0.044)\end{array}$ & $\begin{array}{l}-0.104 * * \\
(0.043)\end{array}$ \\
\hline Profitability & $\begin{array}{l}0.017 \\
(0.014)\end{array}$ & $\begin{array}{l}-0.001 \\
(0.004)\end{array}$ & $\begin{array}{l}0.025^{* *} \\
(0.011)\end{array}$ & $\begin{array}{l}0.028 * * * \\
(0.010)\end{array}$ \\
\hline Firm longevity & $\begin{array}{l}-0.804 * * * \\
(0.158)\end{array}$ & $\begin{array}{l}0.809 * * * \\
(0.157)\end{array}$ & & \\
\hline $\begin{array}{l}\text { Ownership } \\
\text { concentration }\end{array}$ & $\begin{array}{l}0.012 * * * \\
(0.003)\end{array}$ & $\begin{array}{l}0.012 * * * \\
(0.003)\end{array}$ & $\begin{array}{l}0.007 * * * \\
(0.002)\end{array}$ & $\begin{array}{l}0.006 * * * \\
(0.002)\end{array}$ \\
\hline TQ (L1) & & & $\begin{array}{l}0.347 * * * \\
(0.077)\end{array}$ & $\begin{array}{l}0.405 * * * \\
(0.089)\end{array}$ \\
\hline Constant & $\begin{array}{l}1.017 * \\
(0.554)\end{array}$ & $\begin{array}{l}0.692 \\
(0.553)\end{array}$ & $\begin{array}{l}2.318 * * * \\
(0.677)\end{array}$ & $\begin{array}{l}1.702 * \\
(0.660)\end{array}$ \\
\hline $\begin{array}{l}\text { No. of obs } \\
\text { R squared } \\
\text { Wald-chi squared }\end{array}$ & $\begin{array}{l}1189 \\
0.157 \\
219.57 * * *\end{array}$ & $\begin{array}{l}1189 \\
0.155 \\
223.65^{* * *}\end{array}$ & $243.49 * * *$ & $206.62 * * *$ \\
\hline
\end{tabular}

$*$, ** and $* * *$ denote significance at the 10,5 and 1 percent level, respectively 
Table 7. The effect of state financial institution shareholder on firms' Tobin's Q

\begin{tabular}{|c|c|c|c|c|}
\hline Variable & TQ1 & TQ2 & TQ1 (GMM) & TQ2 (GMM) \\
\hline $\begin{array}{l}\text { State financial } \\
\text { institution }\end{array}$ & $\begin{array}{l}0.492 * * * \\
(0.096)\end{array}$ & $\begin{array}{l}0.506 * * * \\
(0.098)\end{array}$ & $\begin{array}{l}0.236^{* *} \\
(0.121)\end{array}$ & $\begin{array}{l}0.273^{* *} \\
(0.128)\end{array}$ \\
\hline Bank loan & $\begin{array}{l}2.284 * * * \\
(0.392)\end{array}$ & $\begin{array}{l}1.310 * * * \\
(0.393)\end{array}$ & $\begin{array}{l}2.686^{* * * *} \\
(0.262)\end{array}$ & $\begin{array}{l}1.670 * * * \\
(0.249)\end{array}$ \\
\hline Size & $\begin{array}{l}-0.017 \\
(0.034)\end{array}$ & $\begin{array}{l}-0.0004 \\
(0.034)\end{array}$ & $\begin{array}{l}-0.135^{* * *} \\
(0.045)\end{array}$ & $\begin{array}{l}-0.099 * * \\
(0.043)\end{array}$ \\
\hline Profitability & $\begin{array}{l}0.018 \\
(0.014)\end{array}$ & $\begin{array}{l}-0.0004 \\
(0.004)\end{array}$ & $\begin{array}{l}0.025^{* *} \\
(0.011)\end{array}$ & $\begin{array}{l}0.029 * * * \\
(0.010)\end{array}$ \\
\hline Firm longevity & $\begin{array}{l}-0.798 * * * \\
(0.157)\end{array}$ & $\begin{array}{l}-0.808 * * * \\
(0.157)\end{array}$ & & \\
\hline $\begin{array}{l}\text { Ownership } \\
\text { concentration }\end{array}$ & $\begin{array}{l}0.012 * * * \\
(0.003)\end{array}$ & $\begin{array}{l}0.012 * * * \\
(0.003)\end{array}$ & $\begin{array}{l}0.008^{* *} \\
(0.002)\end{array}$ & $\begin{array}{l}0.007 * * * \\
(0.002)\end{array}$ \\
\hline TQ (L1) & & & $\begin{array}{l}0.351 * * * \\
(0.077)\end{array}$ & $\begin{array}{l}0.379 * * * \\
(0.086)\end{array}$ \\
\hline Constant & $\begin{array}{l}1.008^{* *} \\
(0.552)\end{array}$ & $\begin{array}{l}0.667 \\
(0.551)\end{array}$ & $\begin{array}{l}2.197 * * * \\
(0.692)\end{array}$ & $\begin{array}{l}1.446 \\
(0.665)\end{array}$ \\
\hline $\begin{array}{l}\text { No. of obs } \\
\text { R squared } \\
\text { Wald-chi squared }\end{array}$ & $\begin{array}{l}1189 \\
0.165 \\
234.36 * * * \\
\end{array}$ & $\begin{array}{l}1189 \\
0.164 \\
239.46 * * * \\
\end{array}$ & $236.50 * * *$ & $\begin{array}{l}780 \\
194.65^{* * *} \\
\end{array}$ \\
\hline
\end{tabular}

$*$, ** and *** denote significance at the 10,5 and 1 percent level, respectively 
Table 8. The effect of bank loans and financial institution shareholder on firms' Tobin's Q

\begin{tabular}{|c|c|c|c|c|}
\hline Variable & TQ1 (2) FE & TQ2 (2) FE & TQ1 (1) FE & TQ2 (1) FE \\
\hline Financial institution & $\begin{array}{l}0.522 * * * \\
(0.135)\end{array}$ & $\begin{array}{l}0.561 * * * \\
(0.135)\end{array}$ & & \\
\hline State financial institution & & & $\begin{array}{l}0.688 * * * \\
(0.119)\end{array}$ & $\begin{array}{l}0.718 * * * \\
(0.119)\end{array}$ \\
\hline Bank loan & $\begin{array}{l}3.307 * * * \\
(0.470)\end{array}$ & $\begin{array}{l}2.319 * * * \\
(0.454)\end{array}$ & $\begin{array}{l}3.152 * * * \\
(0.466)\end{array}$ & $\begin{array}{l}2.145 * * * \\
(0.466)\end{array}$ \\
\hline Size & $\begin{array}{l}-0.337 * * * \\
(0.069)\end{array}$ & $\begin{array}{l}-0.309 * * * \\
(0.068)\end{array}$ & $\begin{array}{l}-0.352^{* * * *} \\
(0.069)\end{array}$ & $\begin{array}{l}-0.322 * * * \\
(0.068)\end{array}$ \\
\hline Profitability & $\begin{array}{l}0.037 \\
(0.026)\end{array}$ & $\begin{array}{l}-0.001 \\
(0.004)\end{array}$ & $\begin{array}{l}0.040 \\
(0.025)\end{array}$ & $\begin{array}{l}-0.001 \\
(0.004)\end{array}$ \\
\hline Ownership concentration & $\begin{array}{l}0.014 * * * \\
(0.003)\end{array}$ & $\begin{array}{l}0.014 * * * \\
(0.003)\end{array}$ & $\begin{array}{l}0.014 * * * \\
(0.003)\end{array}$ & $\begin{array}{l}0.014 * * * \\
(0.003)\end{array}$ \\
\hline Constant & $\begin{array}{l}5.286 * * * \\
(1.070)\end{array}$ & $\begin{array}{l}4.773 * * * \\
(1.056)\end{array}$ & $\begin{array}{l}5.367 * * * \\
(1.048)\end{array}$ & $\begin{array}{l}5.804 * * * \\
(1.043)\end{array}$ \\
\hline No. of obs & 1189 & 1189 & 1189 & 1189 \\
\hline R squared & 0.054 & 0.045 & 0.053 & 0.050 \\
\hline F-test & $25.60 * * *$ & $23.78 * * *$ & $25.31 * * *$ & $25.30 * * *$ \\
\hline
\end{tabular}

$*$,** and $* * *$ denote significance at the 10,5 and 1 percent level, respectively 


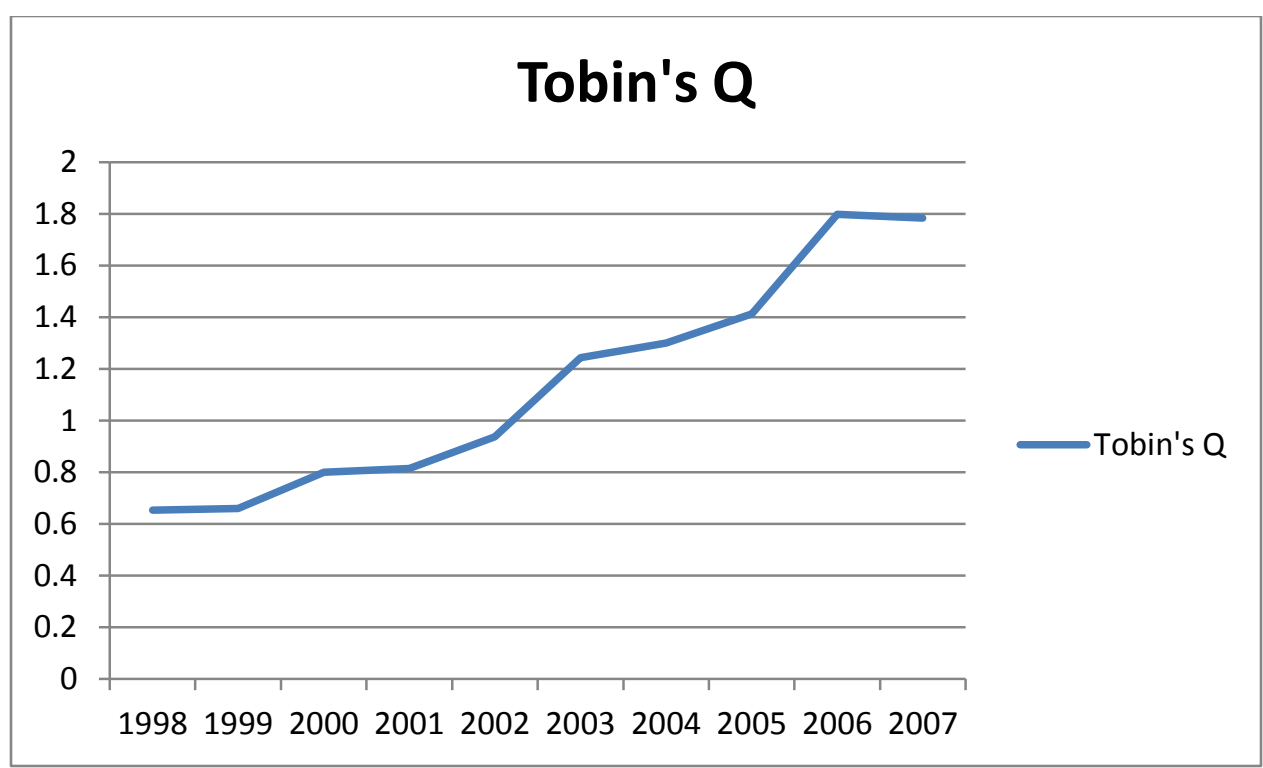

FIGURE 1

Energy sector firms' Tobin's Q during 1998-2007

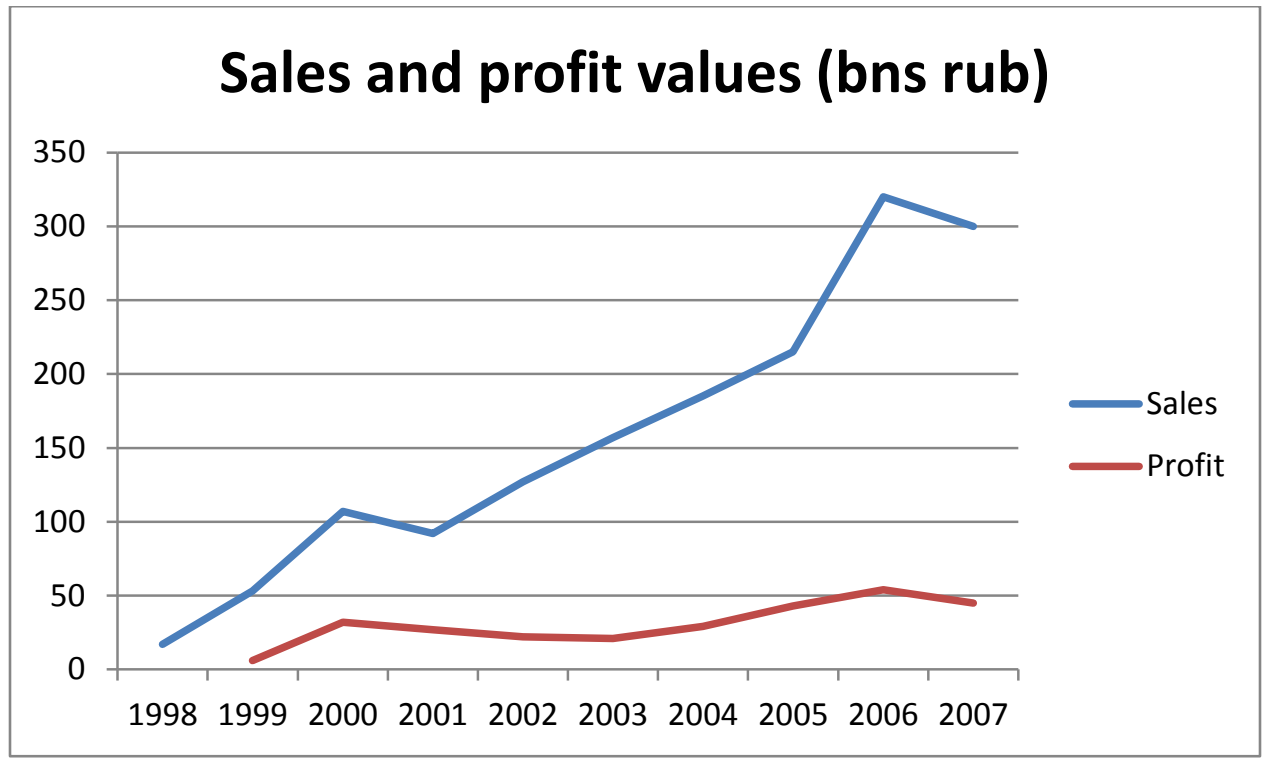

FIGURE 2

The difference between sales and profit trends of energy firms during 1999-2007 